\title{
SUURIMA VAI SUURIMO?
}

\author{
KaARlo Olsonen.
}

Saapunut 15.IX.1947.

Maa- ja kotitalouskirjallisuudessa on viime aikoina alettu käyttää erästä karjalaista sanaa, joka on kansan keskuudessa ollut aivan yleisesti käytännössä Laatokan itäpuoleisissa karjalaismurteissa. Tämä sana, suurima, on lännessä päin kirjakieleen otettuna saanut oudon muodon suurimo, ja on minunkin kielenkäyttöäni tämän sanan suhteen väkisin korjailtu. Sentähden kirjoitin Suomalaisen Kirjallisuuden Seuran kielitoimistolle seuraavanlaisen kyselyn:

\section{Suurima vai suurimo?}

On tietysti oikein, että lainasanojen asemesta aletaan käyttää alkuperäisiä suomenkielisiä sanoja. Mutta kun kansan kielessä käytännössä oleva sana otetaan yleiseen käyttöön kirjakielessä, on se mielestäni otettava siinä muodossa, missä se kansan kielessä vielä elää.

Tällainen sana on suurima. Karjalassa, ainakin Salmissa on aivan yleisesti ollut käytännössä sana suurima a-päätteisenä. Missään muualla Suomessa en ole kuullut tätä sanaa ensinkään käytettävän aikaisemmin.

Viimeaikoina on Maatalousministeriön sekä Kansanhuoltoministeriön julkaisuissa esiintynyt tämä sana muodossa suurimo, siis o-päätteisenä. Sana on ruvennut kummittelemaan muussakin painetussa sanassa o-päätteisenä.

Mistä on peräisin tämä o-päätteinen muoto? Elävä kansan kieli ei sitä tunne.

CANnelrvin suomalaisruotsalaisessa sanakirjassa (painos v. 1920) on sivulla 604 tämä sana kansan kielen mukaisesti näin: suurima, gryn.

Cannelinin ruotsalaissuomalaisessa sanakirjassa (painos v. 1912) on sivulla 230:

gryn, ryyni, suurima,

gryna, murentaa, tehdä ryyniksi, suuria.

Kummassakin sanakirjassa on sana siis kansan kielen mukaisesti a-päätteisenä.

Mahdollisesti o-päätteinen muoto myös on oikea. Mutta millä perusteilla se on oikea? Ja millä perusteilla sitä voidaan puoltaa ennen a-päätteistä muotoa?

En ole ammatiltani kielimies enkä voi kielimiehen tavoin kaikin puolin asiaani perustella. Tahdon kuitenkin oman kantani tueksi rinnastaa eräitä sanamuotoja.

A-päätteisistä sanoista salama ja tavara käytetään muotoja salamoita, tavaroita. Samoin myös sanasta suurima, suurimoita.

On olemassa myös o-päätteisiä sanoja kuten korjaamo, kampaamo, leipomo. Niistä käytetään muotoja korjaamoja, kampaamoja, leipomoja. Korjaamo on paikka, jossa jotakin korjataan, kampaamo on paikka, jossa kammataan ja leipomo on paikka, jossa leivotaan. Samalla tavalla johtaen on suurimo sellainen paikka, jossa suuritaan, jossa tehdään suurimoita eli mylly.

Olen parhaani mukaan selvittänyt kantaan,i, miksi pidän a-päätteistä muotoa, siis muotoa suurima, oikeana ja myös suositeltavana. Koska kielen käytössä on yritettävä yhdenmukaisuuteen ja sentautta käytettävä vain yhtä muotoa, haluaisin, että Suomalaisen Kirjallisuuden Seuran kielitoimisto tekisi kaiken, mikä sen tehtävissä on suurima sanan vakauttamiseksi a-päätteisenä. 
Kielitoimistossa maisteri Hannes Teppo oli suurima-sanasta samaa mieltä kuin minäkin. Hän piti siis a-päätteistä muotoa oikeampana. Kuitenkin hän sanoi esittävänsä tämän asian kielimiesten harkittavaksi. Aikanaan sain häneltä seuraavanlaisen kirjallisen vastauksen:

Pyynnöstä esitän seuraavat seikat suurima-sanasta: Kaikissa vanhoissa lähteissä, jotka tunnen, vanha "ryyniä" merkitsevä sana esiintyy asussa suurima, siis a-loppuisena. Vasta myöhäisinä aikoina se on monikkotaivutuksensa tähden (suurimoiden, suurimoita) alkanut esiintyä o-loppuisena. Sitä on kuitenkin pidettävä harhauttavana ja kielen talouden kannalta vastustettavana, sillä suurima ei mitenkään kuulu tekopaikkaa ilmaisevien mo-sanojen (korjaamo, valimo) ryhmään. Sen sijaan sen sukulaisena pidetään tuttua suurus-sanaa ja teonsanaa suurtaa, joka alunperin lienee merkinnyt suuriksi kappaleiksi rouhimista ja jolla on nimenomainen merkitys "tehdä ryynejä». Nämä sanat esiintyvät vanhassa kansanrunoudessamme, etupäässä itäsuomalaisilla murrealueilla, osaksi vieläkin, sekä mm. LÖNNROTin sanakirjassa (sen lisävihossa jo on tuo harhamuoto suurimo). Itse suurima-sanan asu viittaan teonsanaan suuria - minä suurin, sinä suurit jne., kuten on myös sana pieniä —, mutta en tunne sitä muuta kuin CANNelinin sanakirjasta; epäilemättä se on aikoinaan ollut suurtamisen rinnalla. Suurima on surimisen tulos.

SKS:n kielitoimistossa 4. 3. 1946.

Hannes Teppo, fil.maist.

Ryyni-sana on jo niin kauan ollut vakiintuneena yleiseen käyttöön, ettei ole mitään syytä sitä vieroksua eikä ole edes mahdollistakaan siitä päästä, vaikka se onkin lainasana. Mutta kun suomekielessä on toinenkin sana, vieläpä puhtaasti omaperäinen sana, suurima, ryynin käsitettä ilmaisemassa, ei sitäkään sanaa pitäisi hyleksiä. Jos siis joku haluaa käyttää vaikka vaihteen vuoksi taikka muutenkin paitsi jo yleiseksi vakiintunutta ryyni-sanaa myös sanaa suurima, niin käyttäköön hän sitä oikeassa muodossaan, siinä muodossa, missä se kansan kielessä vielä elää, $a$-loppuisena. 